\title{
THE COMPARABILITY OF THE CONSTRUCT VALIDITY OF SCHEPERS' LOCUS OF CONTROL INVENTORY FOR FIRST AND SECOND LANGUAGE RESPONDENTS
}

\author{
AMANDA BERG \\ Department of Human Resources Management \\ Tshwane University of Technology \\ MICHIEL BUYS \\ PIETER SHAAP \\ CHANTAL OLCKERS \\ mabuys@hakuna.up.ac.za \\ Department of Human Resources Management \\ University of Pretoria
}

\begin{abstract}
The study investigated the construct validity of the Locus of Control Inventory (LCI) for first and second language respondents. The results of confirmatory factor analysis revealed differences in the construct validity of the LCI for the first language $(n=357)$ and second language $(n=387)$ respondents. Item discrimination values, scale reliabilities and factor structures revealed that the three hypothesized domains, (namely external locus of control, internal locus of control and autonomy) underlying the LCI could be confirmed for the first language group, but not for the second language group.
\end{abstract}

\section{OPSOMMING}

Die studie het die konstrukgeldigheid van die Lokus van Beheer Vraelys (LBV) vir eerste en tweede taal respondente ondersoek. Die resultate van ' $n$ bevestigende faktorontleding het verskille in die konstrukgeldigheid van die LBV vir eerste $(\mathrm{N}=357)$ en tweede taal $(\mathrm{N}=387)$ respondente blootgelê. Itemdiskriminasie waardes, skaalbetroubaarhede en faktorstrukture het onthul dat die drie hipotetiese gebiede, (naamlik eksterne lokus van beheer, interne lokus van beheer en outonomie) wat onderliggend is aan die LBV, bevestig word vir die eerste taal groep maar nie vir die tweede taal groep nie.

Locus of control is defined as a generalized expectancy of the extent to which a person perceives that events in his/ her life are consequences of his/her behaviour (Rotter 1966). People described as having an internal locus of control, believe that they can exercise some or a lot of control over events affecting them. By contrast, people who have an external locus of control, tend to believe that they have little or no control over what happens to them. These expectancies are perceived to be the result of many past experiences.

The "locus of control" construct is derived from the Social Learning Theory developed by Rotter (1975). This theory introduced the variable of expectancy and focused on three other general classes of variables, namely behaviours, reinforcements and psychological situations. Rotter gave a central role to expectancy, which is one's belief or subjective judgment that, in a certain psychological situation, a particular behaviour leads to reinforcement. He added that no individual interprets any event or situation in exactly the same way. For one person a situation might look rewarding whereas other individuals might interpret the same event completely differently (Hall and Lindzey, 1985).

According to Schermerhorn Hunt and Osborn (1997), people have personal conceptions about whether the outcomes of their actions are dependent on what they do (an internal orientation) or on factors outside of their personal control (an external orientation). Wise (1999) adds that a person's locus of control has a significant effect on his/her daily life. People with an external locus of control believe that their own actions do not influence future outcomes. This makes such people less likely to work to reach their full potential, due to the motivational, emotional and cognitive deficits

Requests for copies should be addressed to: P Schaap, Department of Human

Resource Management, University of Pretoria, Pretoria 0002 that such a perception creates. People with an internal locus of control are more likely to see the world as capable if being adapted. They believe that hard work and personal abilities will lead to positive outcomes.

The Locus of Control Inventory (LCI) developed by Schepers (1995) is based on the Social Learning Theory and Attribution Theory. Schepers outlines the perception of Locus of Control in terms of the Social Learning Theory as the way in which reinforcement from the social environment takes place, and the effect such reinforcement has on future behaviour. According to Schepers (1995), Social Learning Theory, in conjunction with Attribution Theory, explains the way in which a person selects information according to inherently stable or invariant characteristics.

The Locus of Control Inventory measures three factors, namely Internal Control (the individual believes that outcomes are a consequence of his/her own behaviour); External Control (the individual believes that outcomes are independent of his/her own behaviour) and Autonomy (the individual has an internal locus of control and prefers to work alone) (Schepers, 1995). The LCI was standardized for first-year students whose home language was either predominantly Afrikaans or English (Schepers, 1995).

There are various factors that could cause test differences, including differences in terms of testees' culture, socioeconomic status, language and cognitive style. Owen and Taljaard (1996) have suggested that questions must be asked in such a way that every testee can understand what is expected of him/her in the test situation and can respond freely and comfortably. If that is not done, the language used in the test can contribute to bias. They also emphasize the importance of language proficiency as an influencing factor in differences between cultural groups with regard to test reliabilities and factor structures. 
Horne (2001) investigated job seekers in the South African context with credentials that are not commensurate with their literacy skills. He refered to these incompetent job seekers as language transferees. His studies have shown that the average English language proficiency of Grade 12s in South Africa who indicate an African language as their first language is below the acceptable functional literacy level based on the English Literacy Skills Assessment (ELSA). Horne indicates that only $18 \%$ to $19 \%$ of school-leavers $(\mathrm{n}=988)$ who applied for admission to Technikons during 1999 and 2000 can be considered functionally literate in English (Grade 8 or above). A study done in a "class" of matriculants from the year 2000 $(n=1099)$ enrolled at a traditionally White metropolitan university revealed that only $20 \%$ of these students were functionally literate in English at a Grade 10 level or higher. Schaap Buys Olckers (2003) found lower LCI reliabilities and construct validity for testees who could not complete the LCI in their first language.

The objective of this study was to determine the construct validity of the LCI inventory for first and second language respondents. Cronbach and Meehl (1955) and Owen and Taljaard (1996) define construct validity as the degree to which a test measures a theoretical construct or trait. According to these authors, construct validity is important when the test user wants to evaluate the degree to which a certain trait or construct presumed to be reflected in the test construct, is in fact present in the testee.

\section{RESEARCH DESIGN}

\section{Subjects}

First and second year students registered with the Faculty of Economic and Management Sciences at the University of Pretoria and Technikon Pretoria participated in the study during the 2001 academic year. A convenience sample of 744 students completed the LCI during formal lecture time. The sample consisted of 357 first language respondents (English and Afrikaans), and 387 second language respondents (mainly with an African language as their first language). Personal data for research purposes was provided on a voluntary basis. All data were dealt with in a confidential manner.

\section{Measuring instrument}

The Locus of Control Questionnaire (Schepers, 1999) was used. As it is a normative instrument, it can be used for interindividual comparison. A factor analysis of the scale yielded three factors, namely Internal Locus of Control, Autonomy, and External Locus of Control. Each of these factors defines a separate scale. The three scales were each subjected to an item analysis.

The Locus of Control Inventory consists of 88 items, each in the form of a seven-point scale. The reliabilities of the scales were determined using Cronbach's coefficient alpha (Schepers, 1999). In his 1999 study Schepers reported high reliability coefficients for the Autonomy (0.88), Internal Locus of Control (0.83) and External Locus of Control (0.87) scales.

\section{Data analysis}

The construct comparability of the LCI for first and second language respondents was evaluated by computing coefficients for internal consistency (alpha) and by conducting item and factor analyses respectively. The SPSS (Statistical Package for the Social Sciences) and the EQS program were used to do the required analyses.

The Principal Axis Factoring (PAF) extraction method and direct oblique rotation were used to generate the hypothetical factor solutions for the LCI (Tabachnick and
Fidell, 1989). In accordance with the rational construct approach, the amount of defined theoretical constructs was used to determine the number of factors for rotation purposes (Owen and Taljaard, 1996).

Four criteria were used in the factor analysis to confirm the significance of the factors and the comparability of the factors between groups. The first criterion was the extent to which the factor groupings that were anticipated were confirmed in the factor analysis for the groups that were compared. Secondly, the extent to which the number of significant factors and the variances explained was similar for both groups was examined. Thirdly, it was important that the factor solutions were clear or welldefined and equally interpreted for both groups, and lastly, the factor loadings had to be similar for the groups being compared (De Vellis, 1991).

To verify the amount of significance of factors, the parallel method of Horn (1965), the scree-plots of Cattell (1966), and Kaiser's (1961) criterion were used in this study. According to Zwick and Velicer (1986), Horn's method provides the most accurate estimation of the number of true factors in a complex data set. The congruence coefficient of Tucker (1951) was used to calculate the level of congruence of the rotated factor solutions for the two groups, indicating the level of factor stability across groups.

Confirmatory structural modelling was conducted as an additional measure to test the extent to which the data fitted the proposed LCI model (Rigdon, 1996). Maximum likelihood estimation was used employing the EQS structural equation software. The Bentler-Bonnett normed fit index (NFI) and nonnormed fit index (NNFI), the Comparative Fit Index (CFI), the Bollen Non-normed Fit index (IFI), the Root Mean Squared Error of Approximation (RMSEA), and the Model Chi-square were used as model fit indices (Kelloway, 1998; Medskar, Williams and Holahan, 1994).

Item aggregate values (item parcels) were calculated to control for artefacts in item groupings or factors that have no psychological importance due to the effect of differential item skewness (Comrey and Lee, 1992; Gorsuch 1997). Bagozzi and Heatherton (1994) indicate that the indices obtained from a Confirmatory Factor Analysis could be an underestimation of the model fit values. This could happen when factors contain a large number of items. Bagozzi and Heatherton (1994) have proposed the calculation of item aggregates to obtain more accurate estimates of model fit indices. Item aggregates were built according to rational and theoretical criteria. The assumption was made that each item is an alternative (but equivalent) indicator of the construct to which it has been allocated. The LCI was divided into 23 aggregates of which 19 consisted of four items each and six consisted of three items each. Table 1 indicates how the items were allocated to form aggregates.

\section{RESULTS}

The descriptive statistics for the LCI scales for the first and second language respondents are set out in Table 2. The standard deviation statistics indicate that the first language respondents obtained more homogeneous scores on the Internal Locus of Control scale than second language respondents.

The effect sizes, as described by Cohen (1988), were calculated to determine the practical significance of mean score differences. Table 2 indicates that both Autonomy and External Locus of Control scales reflect small effect sizes and that the Internal Locus of Control scale reflects a medium effect size. The differences between the groups in 
TABLE 1

ITEM AGGREGATES FOR THE LCI

\begin{tabular}{|c|c|c|c|c|c|c|c|c|c|c|c|c|c|c|}
\hline \multicolumn{5}{|c|}{ Autonomy (34 items) } & \multicolumn{5}{|c|}{ Internal locus of control (26 items) } & \multicolumn{5}{|c|}{ External locus of control (28 items) } \\
\hline Aut1 & $1^{*}$ & 2 & 3 & 5 & Int 1 & 6 & 7 & 8 & 10 & Ext1 & 4 & 9 & 12 & 20 \\
\hline Aut2 & 11 * & 13 & 14 & 15 & Int2 & 18 & 19 & 26 & 27 & Ext2 & 34 & 35 & 36 & 38 \\
\hline Aut3 & 16 & 17 & 21 * & 22 & Int3 & 31 & 32 & 33 & 37 & Ext3 & 41 & 43 & 45 & 47 \\
\hline Aut 4 & 23 & 24 & 25 & 28 & Int 4 & 40 & 42 & 48 & 49 & Ext4 & 50 & 51 & 52 & 53 \\
\hline Aut5 & 29 & 30 & $39 *$ & 44 & Int5 & 54 & 55 & 59 & 60 & Ext5 & 56 & 57 & 58 & $65^{*}$ \\
\hline Aut6 & 46 & 62 & 64 & 66 & Int6 & 61 & 63 & 69 & 75 & Ext6 & 72 & 77 & 79 & \\
\hline Aut7 & 67 & 68 & 70 & 71 & Int7 & 76 & 85 & 86 & 87 & Ext7 & 80 & 84 & 88 & \\
\hline Aut8 & $73^{*}$ & 74 & 78 & * & & & & & & & & & & \\
\hline Aut9 & 81 & 82 & 83 & & & & & & & & & & & \\
\hline
\end{tabular}

* Reflected items

respect of both the Autonomy and External Locus of Control scales are of small practical significance. It should be noted that the differences between the second and first language groups on the Internal Locus of Control scale could be of practical significance when cross-language comparisons are made.

TABLE 2

DESCRIPTIVE STATISTICS IN RESPECT OF THE LCI SCALES

\begin{tabular}{lcccccc}
\hline \multicolumn{2}{c}{$\begin{array}{c}\text { Second language } \\
\text { group }(\mathrm{n}=387)\end{array}$} & \multicolumn{2}{c}{$\begin{array}{c}\text { First language } \\
\text { group }(\mathrm{n}=357)\end{array}$} & $\begin{array}{c}\text { Difference } \\
\text { in means }\end{array}$ \\
\hline SD & Mean & & SD & Mean & $\begin{array}{c}\text { Effect } \\
\text { size }\end{array}$ \\
\hline Autonomy & 166,876 & 20,518 & Autonomy & 170,373 & 19,714 & $-0,17$ \\
Internal & 153,84 & 21,40 & Internal & 162,868 & 14,3975 & $-0,49$ \\
External & 95,775 & 19,115 & External & 91,1961 & 20,667 & 0,23 \\
\hline
\end{tabular}

The results for the item analysis for Autonomy for the different groups are set out in Table 3 . There were 11 items $(32 \%$ of the items) that had an item total correlation (discrimination value) lower than 0,20 for second language respondents. A discrimination value of below 0,20 is generally not considered acceptable (Anastasi, 1990; De Vellis, 1991; Anastasi and Urbina, 1997). The items with the low item total correlations also have relatively low item reliabilities. With reference to the first language group, most of the items appear to have acceptable discrimination values and item reliabilities. The alpha coefficients for second language and first language respondents are 0,78 and 0,86 respectively. This can be regarded as a recognisable difference in reliabilities, considering the length of the scale and the equal standard deviations of the scale scores for the groups. The results of the item and reliability analysis for the Autonomy scale imply differences in the construct for the two groups.

The item-analysis results for the Internal Locus of Control scale are set out in Table 4 . All the item-total correlations are above 0,20 for both the second and first language respondents. The Alpha coefficients for the second language and first language groups are 0,86 and 0,84 respectively. The difference in reliability for the above groups can be regarded as small. The results of the item and reliability analysis suggest that the construct is comparable for second and first language respondents.
TABLE 3

ITEM ANALYSIS OF THE LCI AUTONOMY SCALE FOR FIRST AND SECOND LANGUAGE RESPONDENTS

\begin{tabular}{|c|c|c|c|c|c|c|}
\hline & \multicolumn{3}{|c|}{$\begin{array}{l}\text { First language respondents } \\
\qquad(\mathrm{N}=332)\end{array}$} & \multicolumn{3}{|c|}{$\begin{array}{l}\text { Second language respondents } \\
\qquad(\mathrm{N}=286)\end{array}$} \\
\hline & $\begin{array}{l}\text { Item total } \\
\text { Correlation }\end{array}$ & $\begin{array}{l}\text { Alpha if } \\
\text { Item } \\
\text { deleted }\end{array}$ & $\begin{array}{c}\text { Item } \\
\text { Reliability }\end{array}$ & $\begin{array}{c}\text { Item } \\
\text { total } \\
\text { Correlation }\end{array}$ & $\begin{array}{l}\text { Aapha } \\
\text { if Item } \\
\text { deleted }\end{array}$ & $\begin{array}{c}\text { Item } \\
\text { Reliability }\end{array}$ \\
\hline AI1 & 0,4165 & 0,8653 & 0,5821 & 0,1720 & 0,7826 & 0,2966 \\
\hline $\mathrm{AI} 2$ & 0,1873 & 0,8709 & 0,2751 & 0,2286 & 0,7800 & 0,3252 \\
\hline $\mathrm{AI} 3$ & 0,3847 & 0,8661 & 0,4999 & 0,2766 & 0,7781 & 0,4902 \\
\hline AI 4 & 0,3478 & 0,8669 & 0,3743 & 0,4048 & 0,7743 & 0,5199 \\
\hline AI11 & 0,4151 & 0,8653 & 0,5949 & 0,2635 & 0,7789 & 0,5144 \\
\hline AI13 & 0,5152 & 0,8642 & 0,5120 & 0,3092 & 0,7774 & 0,4004 \\
\hline AI14 & 0,4244 & 0,8652 & 0,5549 & 0,3241 & 0,7760 & 0,5622 \\
\hline AI15 & 0,3986 & 0,8658 & 0,6117 & 0,1124 & 0,7862 & 0,2198 \\
\hline AI16 & 0,2548 & 0,8702 & 0,4119 & 0,0820 & 0,7895 & 0,1841 \\
\hline AI17 & 0,3151 & 0,8677 & 0,4312 & 0,1854 & 0,7822 & 0,3349 \\
\hline AI21 & 0,2852 & 0,8683 & 0,3852 & 0,0848 & 0,7864 & 0,1470 \\
\hline AI22 & 0,4279 & 0,8652 & 0,5151 & 0,3363 & 0,7762 & 0,4710 \\
\hline AI23 & 0,2811 & 0,8685 & 0,3936 & 0,2604 & 0,7788 & 0,4475 \\
\hline AI24 & 0,4577 & 0,8644 & 0,6303 & 0,3346 & 0,7755 & 0,6014 \\
\hline AI25 & 0,2663 & 0,8686 & 0,3400 & 0,1955 & 0,7815 & 0,3292 \\
\hline AI28 & 0,2768 & 0,8686 & 0,3880 & 0,2866 & 0,7777 & 0,5323 \\
\hline AI29 & 0,3082 & 0,8678 & 0,4082 & 0,2650 & 0,7786 & 0,4229 \\
\hline AI30 & 0,4250 & 0,8651 & 0,6617 & 0,4132 & 0,7720 & 0,7302 \\
\hline AI39 & 0,3280 & 0,8676 & 0,4930 & 0,0595 & 0,7880 & 0,1097 \\
\hline AI44 & 0,4652 & 0,8646 & 0,5280 & 0,3701 & 0,7745 & 0,5737 \\
\hline AI46 & 0,4876 & 0,8638 & 0,6225 & 0,4232 & 0,7720 & 0,6899 \\
\hline AI62 & 0,1902 & 0,8706 & 0,2647 & 0,3275 & 0,7760 & 0,5326 \\
\hline AI64 & 0,2628 & 0,8686 & 0,3150 & 0,1443 & 0,7839 & 0,2528 \\
\hline AI66 & 0,4890 & 0,8645 & 0,5023 & 0,4231 & 0,7728 & 0,6203 \\
\hline AI67 & 0,4594 & 0,8651 & 0,4677 & 0,4621 & 0,7714 & 0,6664 \\
\hline AI68 & 0,4557 & 0,8647 & 0,5470 & 0,5133 & 0,7686 & 0,8110 \\
\hline AI70 & 0,5372 & 0,8623 & 0,7707 & 0,3650 & 0,7743 & 0,6127 \\
\hline AI71 & 0,3719 & 0,8665 & 0,5619 & 0,1268 & 0,7852 & 0,2391 \\
\hline AI73 & 0,4346 & 0,8649 & 0,6158 & 0,1489 & 0,7839 & 0,2691 \\
\hline AI74 & 0,4809 & 0,8642 & 0,5782 & 0,3958 & 0,7732 & 0,6435 \\
\hline AI78 & 0,2586 & 0,8687 & 0,3184 & 0,0918 & 0,7872 & 0,1803 \\
\hline AI81 & 0,4519 & 0,8646 & 0,5777 & 0,4453 & 0,7718 & 0,6620 \\
\hline AI82 & 0,6087 & 0,8614 & 0,7468 & 0,4324 & 0,7722 & 0,6565 \\
\hline AI83 & 0,4356 & 0,8652 & 0,5039 & 0,4831 & 0,7698 & 0,7649 \\
\hline
\end{tabular}

Scale reliability: First language group: 0,86 Second language group: 0,78 
TABLE 4

ITEM ANALYSIS OF THE LCI INTERNAL LOCUS OF CONTROI FOR FIRST AND SECOND LANGUAGE RESPONDENTS

\begin{tabular}{|c|c|c|c|c|c|c|}
\hline & \multicolumn{3}{|c|}{$\begin{array}{l}\text { First language respondents } \\
\qquad(\mathrm{N}=329)\end{array}$} & \multicolumn{3}{|c|}{$\begin{array}{l}\text { Second language respondents } \\
(\mathrm{N}=306)\end{array}$} \\
\hline & $\begin{array}{l}\text { Item total } \\
\text { Correlation }\end{array}$ & $\begin{array}{l}\text { Alpha if } \\
\text { Item } \\
\text { deleted }\end{array}$ & $\begin{array}{c}\text { Item } \\
\text { Reliability }\end{array}$ & $\begin{array}{c}\text { Item } \\
\text { total } \\
\text { Correlation }\end{array}$ & $\begin{array}{l}\text { Alpha } \\
\text { if Item } \\
\text { deleted }\end{array}$ & $\begin{array}{c}\text { Item } \\
\text { Reliability }\end{array}$ \\
\hline II6 & 0,4051 & 0,8403 & 0,4461 & 0,4841 & 0,8528 & 0,7729 \\
\hline II7 & 0,3970 & 0,8407 & 0,3914 & 0,4023 & 0,8552 & 0,6011 \\
\hline II8 & 0,3038 & 0,8438 & 0,3689 & 0,4048 & 0,8551 & 0,6659 \\
\hline II10 & 0,3791 & 0,8417 & 0,3014 & 0,4902 & 0,8531 & 0,6881 \\
\hline II18 & 0,4040 & 0,8406 & 0,3826 & 0,3262 & 0,8572 & 0,4729 \\
\hline II19 & 0,4685 & 0,8394 & 0,3858 & 0,4230 & 0,8551 & 0,5276 \\
\hline II 26 & 0,2607 & 0,8452 & 0,3111 & 0,2321 & 0,8603 & 0,3936 \\
\hline II27 & 0,3690 & 0,8414 & 0,4083 & 0,4448 & 0,8541 & 0,6531 \\
\hline II31 & 0,4115 & 0,8402 & 0,1432 & 0,4200 & 0,8551 & 0,5399 \\
\hline II32 & 0,3577 & 0,8419 & 0,4300 & 0,2688 & 0,8599 & 0,5173 \\
\hline II33 & 0,3815 & 0,8410 & 0,4240 & 0,4090 & 0,8550 & 0,6373 \\
\hline II37 & 0,3520 & 0,8420 & 0,3858 & 0,4500 & 0,8539 & 0,6765 \\
\hline II 40 & 0,4201 & 0,8397 & 0,5034 & 0,3336 & 0,8577 & 0,6346 \\
\hline II 42 & 0,3218 & 0,8430 & 0,3574 & 0,4305 & 0,8544 & 0,6712 \\
\hline II 48 & 0,2723 & 0,8450 & 0,3388 & 0,3119 & 0,8583 & 0,5845 \\
\hline II 49 & 0,4769 & 0,8395 & 0,3698 & 0,4764 & 0,8538 & 0,6069 \\
\hline II54 & 0,2797 & 0,8446 & 0,3372 & 0,3352 & 0,8576 & 0,6364 \\
\hline II55 & 0,4455 & 0,8391 & 0,4671 & 0,4541 & 0,8537 & 0,7178 \\
\hline II59 & 0,3953 & 0,8406 & 0,4581 & 0,4146 & 0,8548 & 0,7399 \\
\hline II60 & 0,4202 & 0,8402 & 0,3981 & 0,4253 & 0,8545 & 0,6675 \\
\hline II61 & 0,3702 & 0,8415 & 0,4451 & 0,3476 & 0,8570 & 0,6219 \\
\hline II63 & 0,4410 & 0,8396 & 0,4110 & 0,5042 & 0,8529 & 0,6765 \\
\hline II69 & 0,3961 & 0,8406 & 0,4495 & 0,3519 & 0,8566 & 0,4905 \\
\hline II75 & 0,5804 & 0,8356 & 0,5550 & 0,4185 & 0,8548 & 0,6387 \\
\hline II76 & 0,3027 & 0,8443 & 0,4051 & 0,3946 & 0,8557 & 0,7841 \\
\hline II85 & 0,3478 & 0,8425 & 0,4616 & 0,4146 & 0,8548 & 0,7176 \\
\hline II86 & 0,3081 & 0,8440 & 0,4075 & 0,4071 & 0,8551 & 0,6300 \\
\hline II87 & 0,4251 & 0,8396 & 0,4782 & 0,4366 & 0,8542 & 0,6770 \\
\hline
\end{tabular}

Scale reliability: First language group: 0,84

Second language group: 0,86

The results for the item analysis for the External Locus of Control scale for the first and second language respondents are set out in Table 5 . There are three items $(12 \%$ of the items) with an item total correlation value below 0,20 and relatively low item reliabilities for the second language group. All the item total correlations are acceptable for the first language respondents. The alpha coefficients for the second and first language respondents are 0,78 and 0,87 respectively. This can be regarded as a recognisable difference in reliabilities, especially considering the length of the scale and the equal standard deviations of the scale scores for the groups. The item and reliability analyses imply differences in the construct that is measured for both these groups.

The results of the factor analysis performed on the LCI indicate differences in the factor structures for second and first language respondents. The sample sizes for both the second and first language respondents were adequate, according to the Kaiser-Meyer-Olkin (KMO) measure of sample size (Kim and Mueller, 1978). The KMO-values were 0,883 and 0,888 respectively for the second and first language respondents. These values can be considered highly acceptable.

The postulated theoretical model of Schepers (1999) was used to determine the number of factors that were rotated. An oblique rotation method was used, as the LCI factors can be considered to be related (Schepers,1995). The quality of the factor solutions was evaluated using the level of interpretability and the simplicity of the structure obtained (DeVellis, 1991; Tinsley and Tinsley, 1987; Tabachnick and Fidell, 1989). Factor loadings of 0,30 and higher were considered acceptable (Tabachnick and Fidell, 1989). Small deviations from the 0,30 criterion were allowed to account for possible differences in sample homogeneity.

TABLE 5

ITEM ANALYSIS OF THE LCI INTERNAL LOCUS OF CONTROL FOR FIRST AND SECOND LANGUAGE RESPONDENTS

\begin{tabular}{|c|c|c|c|c|c|c|}
\hline & \multicolumn{3}{|c|}{$\begin{array}{l}\text { First language respondents } \\
\qquad(\mathrm{N}=325)\end{array}$} & \multicolumn{3}{|c|}{$\begin{array}{l}\text { Second language respondents } \\
\qquad(\mathrm{N}=289)\end{array}$} \\
\hline & $\begin{array}{l}\text { Item total } \\
\text { Correlation }\end{array}$ & $\begin{array}{l}\text { Alpha if } \\
\text { Item } \\
\text { deleted }\end{array}$ & $\begin{array}{c}\text { Item } \\
\text { Reliability }\end{array}$ & $\begin{array}{c}\text { Item } \\
\text { total } \\
\text { Correlation }\end{array}$ & $\begin{array}{l}\text { Alpha } \\
\text { if Item } \\
\text { deleted }\end{array}$ & $\begin{array}{c}\text { Item } \\
\text { Reliability }\end{array}$ \\
\hline EI4 & 0,3177 & 0,8751 & 0,5437 & 0,2317 & 0,7827 & 0,4556 \\
\hline EI9 & 0,2487 & 0,8760 & 0,3177 & 0,1494 & 0,7866 & 0,2846 \\
\hline EI12 & 0,5153 & 0,8696 & 0,8810 & 0,2527 & 0,7813 & 0,4354 \\
\hline EI20 & 0,3429 & 0,8742 & 0,5168 & 0,1926 & 0,7845 & 0,3690 \\
\hline EI34 & 0,4147 & 0,8725 & 0,7252 & 0,1971 & 0,7844 & 0,3842 \\
\hline EI35 & 0,4643 & 0,8711 & 0,8838 & 0,3392 & 0,7770 & 0,6883 \\
\hline EI36 & 0,4768 & 0,8707 & 0,7880 & 0,3825 & 0,7751 & 0,6759 \\
\hline EI38 & 0,5627 & 0,8684 & 0,9117 & 0,3177 & 0,7782 & 0,5885 \\
\hline EI41 & 0,5140 & 0,8698 & 0,8171 & 0,2930 & 0,7794 & 0,5419 \\
\hline EI43 & 0,3960 & 0,8731 & 0,7024 & 0,2967 & 0,7793 & 0,6079 \\
\hline EI45 & 0,5490 & 0,8692 & 0,8059 & 0,4570 & 0,7704 & 0,9354 \\
\hline EI47 & 0,3297 & 0,8746 & 0,5213 & 0,2870 & 0,7799 & 0,6025 \\
\hline EI50 & 0,4442 & 0,8717 & 0,6504 & 0,3731 & 0,7758 & 0,6254 \\
\hline EI51 & 0,5133 & 0,8701 & 0,7323 & 0,2906 & 0,7795 & 0,4855 \\
\hline EI52 & 0,3112 & 0,8753 & 0,5244 & 0,3000 & 0,7793 & 0,6449 \\
\hline EI53 & 0,4148 & 0,8724 & 0,6861 & 0,4477 & 0,7712 & 0,8758 \\
\hline EI56 & 0,4611 & 0,8712 & 0,7475 & 0,3924 & 0,7744 & 0,7342 \\
\hline EI57 & 0,5111 & 0,8699 & 0,8104 & 0,2659 & 0,7811 & 0,5596 \\
\hline EI58 & 0,4070 & 0,8727 & 0,7128 & 0,3381 & 0,7770 & 0,6740 \\
\hline EI65 & 0,2294 & 0,8773 & 0,3761 & 0,3495 & 0,7768 & 0,5964 \\
\hline EI72 & 0,4403 & 0,8718 & 0,6696 & 0,3554 & 0,7764 & 0,6354 \\
\hline EI77 & 0,3274 & 0,8748 & 0,5421 & 0,2222 & 0,7838 & 0,4829 \\
\hline EI79 & 0,5793 & 0,8678 & 0,9850 & 0,3275 & 0,7778 & 0,5735 \\
\hline EI80 & 0,5573 & 0,8687 & 0,8802 & 0,4316 & 0,7724 & 0,8042 \\
\hline EI84 & 0,5663 & 0,8685 & 0,8781 & 0,3027 & 0,7789 & 0,5728 \\
\hline EI88 & 0,3833 & 0,8732 & 0,5710 & 0,3286 & 0,7777 & 0,5789 \\
\hline
\end{tabular}

Scale reliability: First language group: 0,87

Second language group: 0,78

Figure 1 indicates that two significant factors can be identified for the second language respondents based on the results of the scree-test (Cattell, 1966) and Horn's (1965) criterion. A clear break can be observed on the scree-plot between Factors Two and Three. The eigenvalues of the random data set intersect the eigenvalues for the true data set between Factors Two and Three for the second language group, indicating two significant factors (Horn, 1965). The results reported in Table 6 indicate that the two significant factors explain $36,21 \%$ of the total variance. Kaiser's (1961) criterion clearly overestimates the number of true factors for the data set (Tabachnick and Fidell, 1989). According to Table 6. there are clear signs of over-factoring, as limited items loaded above 0,30 on Factor Three. The proposed threemodel structure for the second language respondents is not well-defined or interpretable and does not resemble a simple structure. It is evident from the results that the three-factor structure proposed by Schepers (1999) did not hold for the second language respondents. 


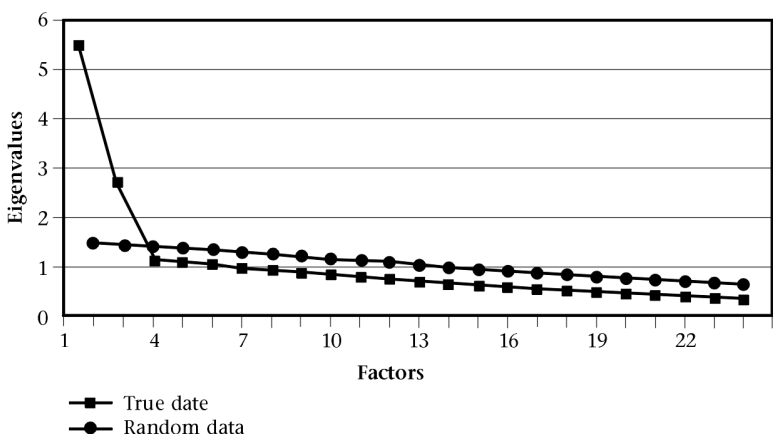

Figure 1: Scree plot second language

TABLE 6

FACTOR EIGEN VALUES AND VARIANCE EXPLAINED FOR FIRST AND SECOND LANGUAGE RESPONDENTS

\begin{tabular}{|c|c|c|c|c|c|c|c|}
\hline \multirow[t]{2}{*}{ Factor } & \multicolumn{3}{|c|}{$\begin{array}{l}\text { Second language } \\
\text { respondents }(\mathrm{N}=387)\end{array}$} & \multirow[t]{2}{*}{ Factor } & \multicolumn{3}{|c|}{$\begin{array}{l}\text { First language } \\
\text { respondents }(\mathrm{N}=357)\end{array}$} \\
\hline & Total & $\begin{array}{l}\% \text { of } \\
\text { variance }\end{array}$ & $\begin{array}{l}\text { Cumula- } \\
\text { tive } \%\end{array}$ & & total & $\begin{array}{l}\% \text { of } \\
\text { variance }\end{array}$ & $\begin{array}{l}\text { Cumula- } \\
\text { tive } \%\end{array}$ \\
\hline 1 & 5,536 & 24,068 & 24,068 & 1 & 6,753 & 29,361 & 29,361 \\
\hline 2 & 2,794 & 12,146 & 36,214 & 2 & 2,927 & 12,728 & 42,089 \\
\hline 3 & 1,139 & 4,954 & 41,167 & 3 & 1,865 & 8,107 & 50,196 \\
\hline 4 & 1,075 & 4,676 & 45,843 & 4 & 1,009 & 4,387 & 54,583 \\
\hline 5 & 1,029 & 4,473 & 50,316 & 5 & 0,928 & 4,034 & 58,618 \\
\hline 6 & 0,995 & 4,152 & 54,468 & 6 & 0,838 & 3,644 & 62,262 \\
\hline 7 & 0,887 & 3,856 & 58,324 & 7 & 0,790 & 3,436 & 65,698 \\
\hline 8 & 0,850 & 3,696 & 62,020 & 8 & 0,718 & 3,122 & 68,820 \\
\hline 9 & 0,788 & 3,424 & 65,444 & 9 & 0,687 & 2,986 & 71,806 \\
\hline 10 & 0,777 & 3,380 & 68,825 & 10 & 0,654 & 2,841 & 74,647 \\
\hline 11 & 0,741 & 3,220 & 72,045 & 11 & 0,623 & 2,709 & 77,356 \\
\hline 12 & 0,709 & 3,083 & 75,127 & 12 & 0,578 & 2,514 & 79,870 \\
\hline 13 & 0,686 & 2,984 & 78,111 & 13 & 0,570 & 2,477 & 82,347 \\
\hline 14 & 0,627 & 2,726 & 80,837 & 14 & 0,530 & 2,303 & 84,650 \\
\hline 15 & 0,604 & 2,624 & 83,461 & 15 & 0,504 & 2,193 & 86,843 \\
\hline 16 & 0,589 & 2,560 & 86,022 & 16 & 0,475 & 2,064 & 88,908 \\
\hline 17 & 0,545 & 2,371 & 88,392 & 17 & 0,459 & 1,995 & 90,902 \\
\hline 18 & 0,521 & 2,265 & 90,658 & 18 & 0,441 & 1,916 & 92,818 \\
\hline 19 & 0,479 & 2,082 & 92,740 & 19 & 0,402 & 1,746 & 94,564 \\
\hline 20 & 0,465 & 2,023 & 94,763 & 20 & 0,367 & 1,594 & 96,158 \\
\hline 21 & 0,422 & 1,835 & 96,598 & 21 & 0,335 & 1,457 & 97,615 \\
\hline 22 & 0,409 & 1,780 & 98,378 & 22 & 0,296 & 1,287 & 98,901 \\
\hline 23 & 0,373 & 1,622 & 100,000 & 23 & 0,253 & 1,099 & 100,00 \\
\hline
\end{tabular}

Extraction method: Principal axis factoring Extraction method: Principal axis factoring

Figure 2 and Table 6 set out the results for the factor analyses for first language respondents. Kaiser's (1961) criterion, Horn's (1965) criterion and the scree-test indicate three significant factors for the above group. A clear break can be observed between Factors Three and Four, indicating three significant factors according to the scree-test. Kaiser's eigenvalue criterion indicates three distinct factors. The eigenvalues for the random data set intersect the eigenvalues for the true data set between the third and fourth factor, indicating a three-factor solution. The three factors explain up to $50 \%$ of the total variance for the data set (Table 6). A clear, well-defined, interpretable and simple factor structure can be observed in Table 6 for the first language respondents.

The congruence coefficient of Tucker (1951) was used to determine the level of congruence between factor structures as a measure of factor similarity and stability. According to Tabachnick and Fidell (1989), marker variables can be used to identify factors. It is clear from the results in Table 7 (the three-factor solution) that Factor One can be identified as the Internal Locus of Control scale for the second language respondents. Factor Two has been identified as the External Locus of Control scale for the second language respondents. Factor Three has retained certain elements of the Autonomy scale but is poorly defined for the second language respondents and can be considered an artefact. Factor One is clearly defined as the Autonomy scale for the first language respondents. The External Locus of Control scale is clearly visible as Factor Two for the first language respondents. The Internal Locus of Control scale has been identified as Factor Three for the first language respondents.

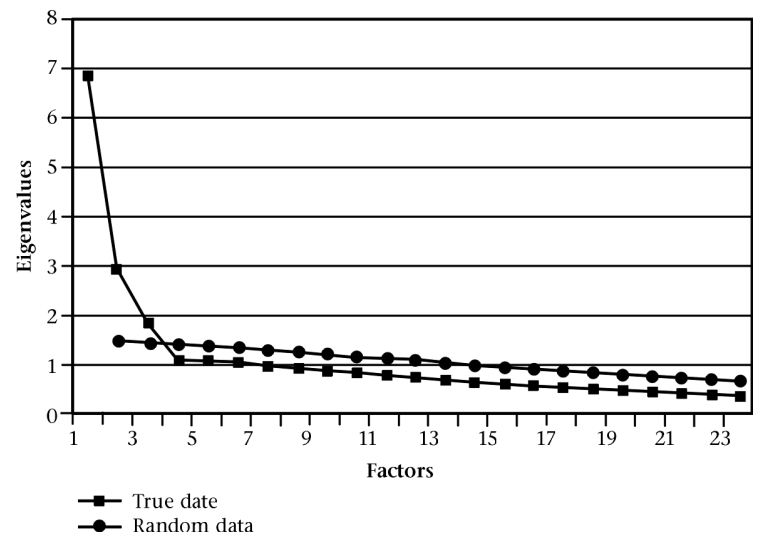

Figure 2: Scree plot first language

TABLE 7

ROTATED PATTERN MATRIX FOR SECOND AND FIRST LANGUAGE RESPONDENTS (THREE FACTOR SOLUTION)

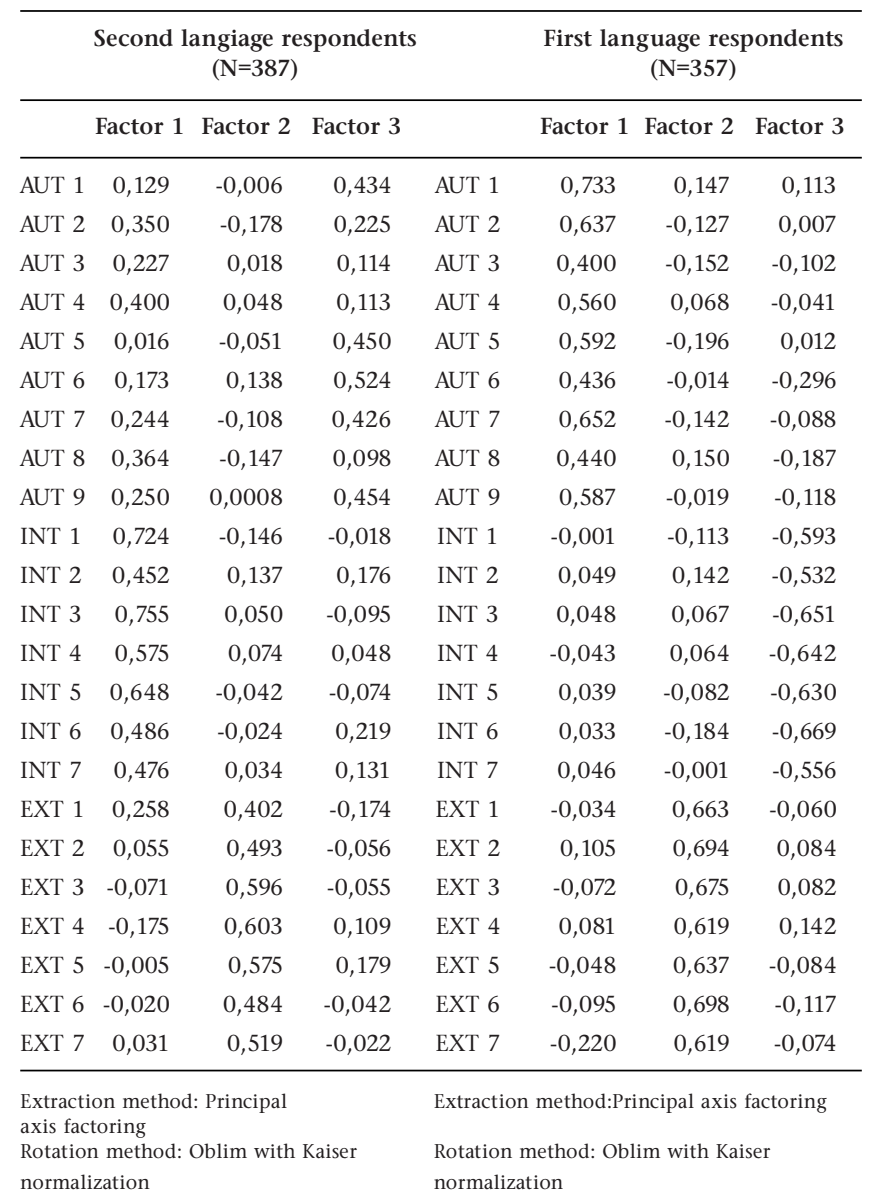


Table 8 sets out the Two-Factor solution. For both the second and first language respondents, Factor One has been identified as a combination of Autonomy and Internal Locus of Control and Factor Two as External Locus of Control.

The congruence coefficient (the three-factor solution) for the Internal Locus of Control scale in respect of the two groups is 0.91 and is considered congruent (Tucker, 1951). The congruence coefficient for the External Locus of Control scale in respect of the groups in question is 0.95 . The External Locus of Control scale can be considered highly stable for the sample groups. The congruence coefficient for the Autonomy scale between groups is 0.83 and is not considered congruent. It is clear from the results that the External Locus of Control and Internal Locus of Control scales are stable for the groups included in the study. The congruence coefficient (two-factor solution) for the Internal Locus of Control scale in respect of the two groups is 0.99. and for the External Locus of Control, it is 0.93. This can be considered congruent.

The factor correlation matrix for the rotated factors clearly differs for the two groups, which signifies limited comparability in the rotated factor structures for the groups.

TABLE 8

ROTATED PATTERN MATRIX FOR SECOND AND FIRST LANGUAGE RESPONDENTS (TWO-FACTOR SOLUTION)

\begin{tabular}{|c|c|c|c|c|c|}
\hline \multicolumn{3}{|c|}{$\begin{array}{l}\text { Second langiage respondents } \\
\qquad(\mathrm{N}=387)\end{array}$} & & \multicolumn{2}{|c|}{$\begin{array}{l}\text { First language respondents } \\
\qquad(\mathrm{N}=357)\end{array}$} \\
\hline & Factor 1 & Factor 2 & & Factor 1 & Factor 2 \\
\hline AUT 1 & 0,465 & $-0,051$ & AUT 1 & 0,336 & $-0,169$ \\
\hline AUT 2 & 0,520 & $-0,174$ & AUT 2 & 0,376 & $-0,377$ \\
\hline AUT 3 & 0,310 & 0,024 & AUT 3 & 0,338 & $-0,293$ \\
\hline AUT 4 & 0,476 & 0,072 & AUT 4 & 0,384 & $-0,153$ \\
\hline AUT 5 & 0,369 & $-0,107$ & AUT 5 & 0,342 & $-0,428$ \\
\hline AUT 6 & 0,571 & 0,080 & AUT 6 & 0,557 & $-0,142$ \\
\hline AUT 7 & 0,572 & $-0,139$ & AUT 7 & 0,476 & $-0,384$ \\
\hline AUT 8 & 0,432 & $-0,125$ & AUT 8 & 0,446 & 0,293 \\
\hline AUT 9 & 0,598 & $-0,035$ & AUT 9 & 0,472 & $-0,236$ \\
\hline INT 1 & 0,680 & $-0,072$ & INT 1 & 0,559 & $-0,016$ \\
\hline INT 2 & 0,575 & 0,157 & INT 2 & 0,554 & 0,206 \\
\hline INT 3 & 0,642 & 0,131 & INT 3 & 0,658 & 0,149 \\
\hline INT 4 & 0,590 & 0,122 & INT 4 & 0,587 & 0,178 \\
\hline INT 5 & 0,616 & 0,020 & INT 5 & 0,622 & 0,022 \\
\hline INT 6 & 0,645 & $-0,006$ & INT 6 & 0,644 & $-0,087$ \\
\hline INT 7 & 0,563 & 0,062 & INT 7 & 0,564 & 0,068 \\
\hline EXT 1 & 0,104 & 0,445 & EXT 1 & 0,073 & 0,669 \\
\hline EXT 2 & 0,001 & 0,506 & EXT 2 & 0,014 & 0,606 \\
\hline EXT 3 & $-0,123$ & 0,597 & EXT 3 & $-0,089$ & 0,670 \\
\hline EXT 4 & $-0,091$ & 0,564 & EXT 4 & $-0,056$ & 0,537 \\
\hline EXT 5 & 0,128 & 0,544 & EXT 5 & 0,088 & 0,656 \\
\hline EXT 6 & $-0,061$ & 0,489 & EXT 6 & 0,093 & 0,741 \\
\hline EXT 7 & 0,052 & 0,526 & EXT 7 & $-0,028$ & 0,710 \\
\hline \multicolumn{3}{|c|}{$\begin{array}{l}\text { Extraction method: Principal axis } \\
\text { factoring }\end{array}$} & \multicolumn{3}{|c|}{$\begin{array}{l}\text { Extraction method: Principal axis } \\
\text { factoring }\end{array}$} \\
\hline \multicolumn{3}{|c|}{ Rotation method: Oblimin with } & \multirow{2}{*}{\multicolumn{3}{|c|}{ Rotation method: Oblimin with }} \\
\hline \multicolumn{3}{|c|}{ Kaiser normalization } & & & \\
\hline
\end{tabular}

The inter-correlation matrix in Table 9 shows clear differences in the interrelationships between the LCI scales for the two groups. The significance of the differences in the correlation coefficients for the two groups was determined by calculating z-values (Kanji, 1993). The correlation between the Autonomy scale and the Internal Locus of Control scale is significantly higher $(z=-5,02$; $p=$ 0,05 ) for the Second Language group than for the First
Language group. The Autonomy scale appears not to be similar for the two groups in terms of its relation with the Internal Locus of Control scale. The External Locus of Control scale's correlation with the Autonomy scale differs significantly $(z=5,28 ; p=0,05)$ between the groups. The correlation between the Internal and External Locus of Control scales differ significantly $(z=2,34 ; p=0,05)$ for the groups. The correlation coefficients between the Internal and External Locus of Control scales are small for both groups, which verifies Schepers's (1995) conclusion that the Internal and External loci of control can be seen as separate constructs and not as bi-polar opposites.

TABLE 9

SCALE INTERCORRELATIONS MATRIX FOR FIRST AND SECOND LANGUAGE RESPONDENTS

\begin{tabular}{lccc}
\hline & Autonomy & Internal & External \\
\hline Autonomy & 1,000 & 0,703 & $-0,083$ \\
Internal & 0,465 & 1,000 & 0,043 \\
External & $-0,440$ & $-0,212$ & 1,000 \\
\hline
\end{tabular}

Note: Correlations for the second language group are given in the upper triangular matrix and for the first language group in the lower triangular matrix

The structural equation models for the three hypothesized domains underlying the LCI for second language respondents (the three-factor solution) are given in Table 10 and Figure 3 respectively. The latent variables have been allowed to correlate with one another. With regard to the second language respondents, the NFI value is 0,823 . The NNFI value is 0,903 ; the CFI value is 0,913 ; and the IFI value is 0,914 . A value of 0.90 is generally considered to be an indicator of a model with with a good fit. for all the above-mentioned fit indices (Bentler, 1990; Bentler and Bonnett, 1980; Steiger, 1995).

With regard to the three-factor solution, the RMSEA value for second language respondents is 0,045. Hair et al (1995) consider RMSEA-values between 0,05 and 0,08 to be indicative of acceptable fit. Steiger (1995) considers RMSEA-values of less than 0.10 acceptable.

The chi-square (three-factor solution) was 401,856 , based upon 227 df $(p=0,01)$ for second language respondents. This chisquare measure for second language respondents is highly significant and indicates a poor model fit. However, given the current sample size, it would be incorrect to conclude poor fit based on the significance of the chi-square index. The chisquare/df ratio is 1,77 for second language respondents. Ratios between 2 and 5 can be interpreted as indicating a good fit (Kelloway, 1998).

The structural equation models for the two hypothesized domains underlying the LCI for second language respondents (the two-factor solution) are set out in Table 10 and Figure 4 respectively. The latent variables have been allowed to correlate with one another. I respect of the second language respondents, the NFI value is 0,804 ; the NNFI value is 0,882 ; the CFI value is 0,893 and the IFI value is 0,050 .

With regard to the two-factor solution, the RMSEA value for second language respondents is 0,050. Hair et al (1995) consider RMSEA-values between 0,05 and 0,08 to be indicative of acceptable fit. Steiger (1995) considers RMSEA-values of less than 0,10 acceptable.

The chi-square (the two-factor solution) was 445,203 based upon $229 \mathrm{df}(\mathrm{p}=0,01)$ for second language respondents. This chi-square measure for second language respondents is highly significant and indicates a poor model fit. However, given the current 


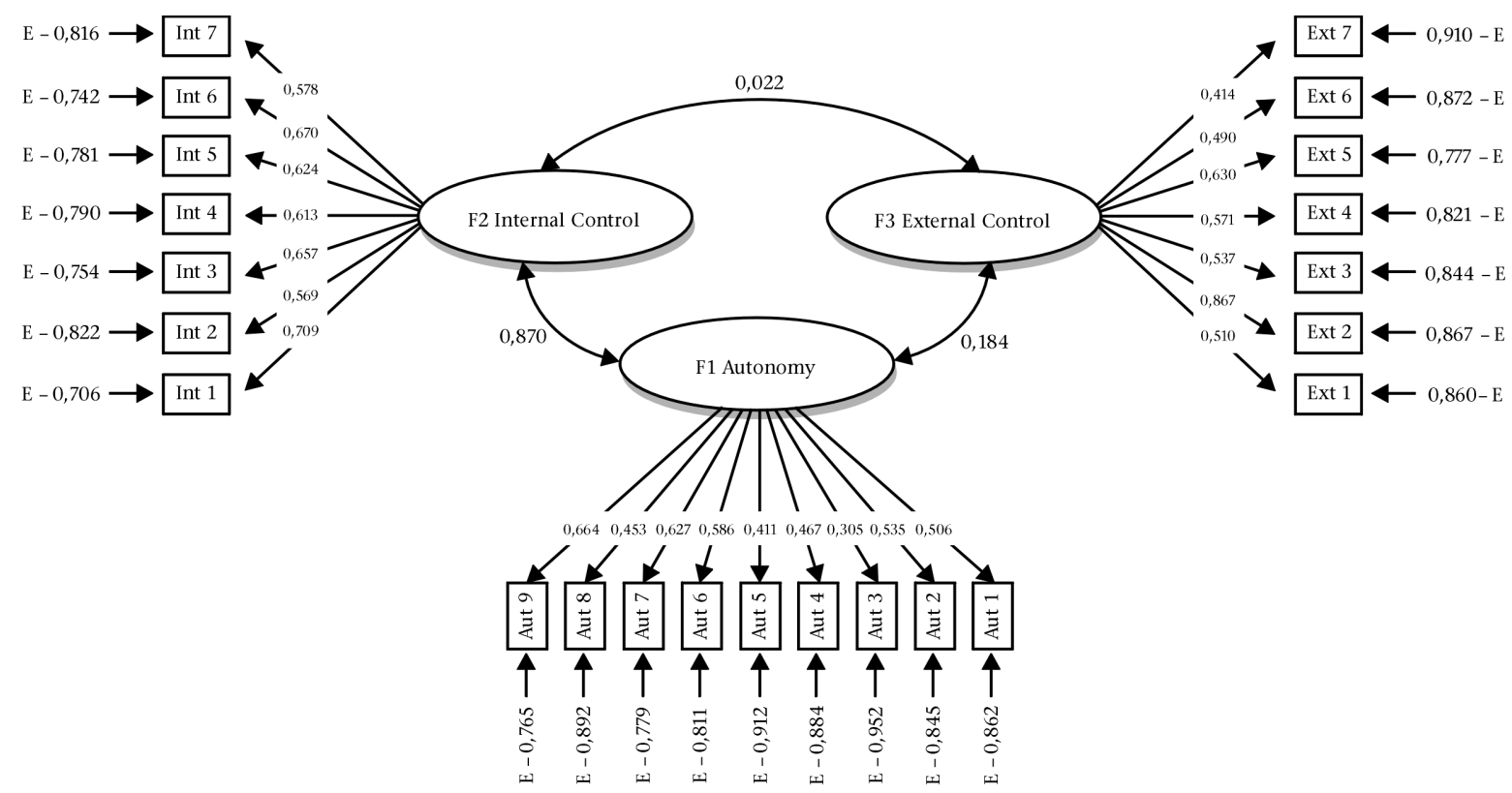

Figure 3: Standardised estimated parameters of the three-factor LCI model for the second language group

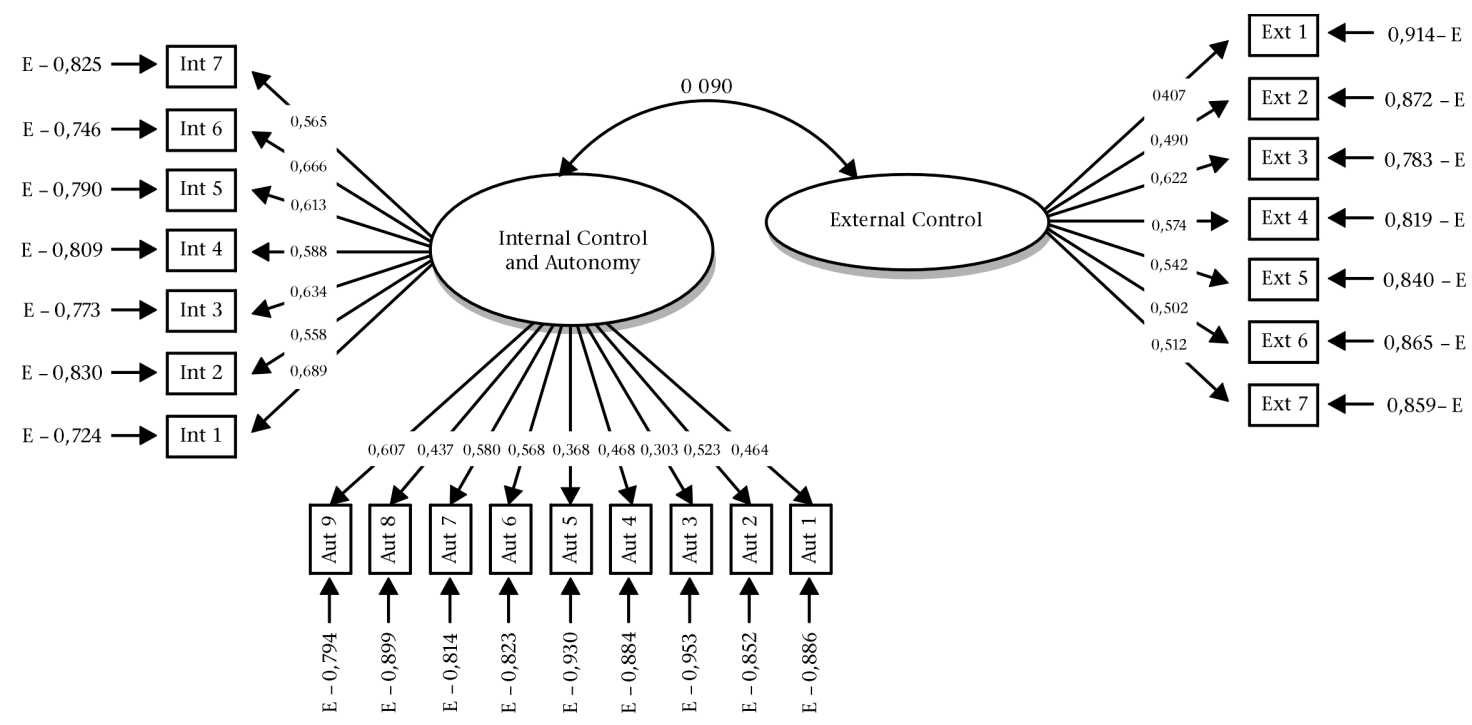

Figure 4: Standardised estimated parameters of the two-factor LCI model for the second language

sample size, it would be premature to conclude poor fit based on the significance of the chi-square index. The chi-square/df ratio is 1,944 for second language respondents.

\section{TABLE 10}

FIT INDICES FOR SECOND LANGUAGE RESPONDENTS

\begin{tabular}{lcc}
\hline $\begin{array}{c}\text { Second language } \\
\text { respondents } \\
\text { (N=387) }\end{array}$ & $\begin{array}{c}\text { Three factor } \\
\text { solution }\end{array}$ & $\begin{array}{c}\text { Two-factor } \\
\text { solution }\end{array}$ \\
\hline CHI Square & 401,856 & 445,203 \\
(DF) & $(227)$ & $(229)$ \\
NFI & 0,823 & 0,804 \\
NNFI & 0,903 & 0,882 \\
CFI & 0,913 & 0,893 \\
IFI & 0,914 & 0,894 \\
RMSEA & 0,045 & 0,050 \\
\hline
\end{tabular}

Although some of the fit indices are marginally to recognizably lower than the accepted value for a good model fit, it can still be concluded that the two-factor model fits the data reasonably well. A matter of concern is the high correlation of 0,870 between the Autonomy and the Internal Locus of Control latent variables. Gorsuch (1997) indicates that confirmatory structural equations model analysis could fail to provide clear results when correlations between latent factors are too high. The high correlation between the Autonomy and the Internal Locus of Control latent variables suggests that the Autonomy and Internal Locus of Control constructs cannot necessarily be distinguished as separate constructs for the second language respondents. It can thus be concluded that the items that were constructed for the Autonomy and Internal Locus of Control scale overlap to such an extent that the scales cannot be considered factorially pure for the second language respondents. To test this conclusion, the aggregates for the Autonomy and Internal Locus of Control scales were grouped together as one of the factors in a two-factor model hypothesis, as illustrated in Figure 4.

Although some of the fit indices are lower than the accepted value for a good model fit, it can also be concluded that the 
two-factor model fits the data reasonably well. It can further be concluded that the values for the two-factor model fit indices are very similar to the values of the three-factor model fit indices for the second language respondents. There thus appears to be very little distinction between the items for the Autonomy and Internal Locus of Control constructs for second language respondents and can they can be interpreted as a single latent construct.

Both the two-factor model and the three-factor model of the LCI were also tested for the first language respondents. Figure 5 presents the path diagram and fitted coefficients for the three-factor model. With regard to Table 11 for the first language respondents (the three factor solution), the NFI value is 0,819 ; the NNFI value is 0,868 ; the CFI value is 0,882 ; and the IFI value is 0,883 . All of these values are close to 0,90 , which may indicate that this is also a model with a relatively good fit. The RMSEA value for first language respondents was 0,065 . The chi-square was 569,724 , based also on $227 \mathrm{df}(\mathrm{p}=0,01)$ for first language respondents. The chi-square/df ratio is 2,50 for first language respondents. Ratios between 2 and 5 have been interpreted as indicating a good fit (Kelloway, 1998).
Figure 6 presents the path diagram and fitted coefficients for the two-factor model for first language respondents. With regard to the first language respondents (the twofactor model), the NFI value is 0,692 ; the NNFI value is 0,716 ; the CFI value is 0,774 ; and the IFI value is 0,746 . None of these values are close to 0,90 , which may indicate that this is not a model with a relatively good fit. The RMSEA value for first language respondents was 0,096. The chi-square was 969,247, based on $228 \mathrm{df}$ $(\mathrm{p}=0,01)$ for first language respondents. The chi-square/ df ratio was 4,25 for first language respondents. Ratios between 2 and 5 have been interpreted as indicating a good fit (Kelloway, 1998).

It is clear that the three-factor model fits the data considerably better than the two-factor model. These results suggest that the three-factor model is relatively more pure and has less error variance than the two-factor model for the first language respondents. There appears to be a clearer distinction between the Autonomy and Internal Locus of Control latent variables for first language respondents.

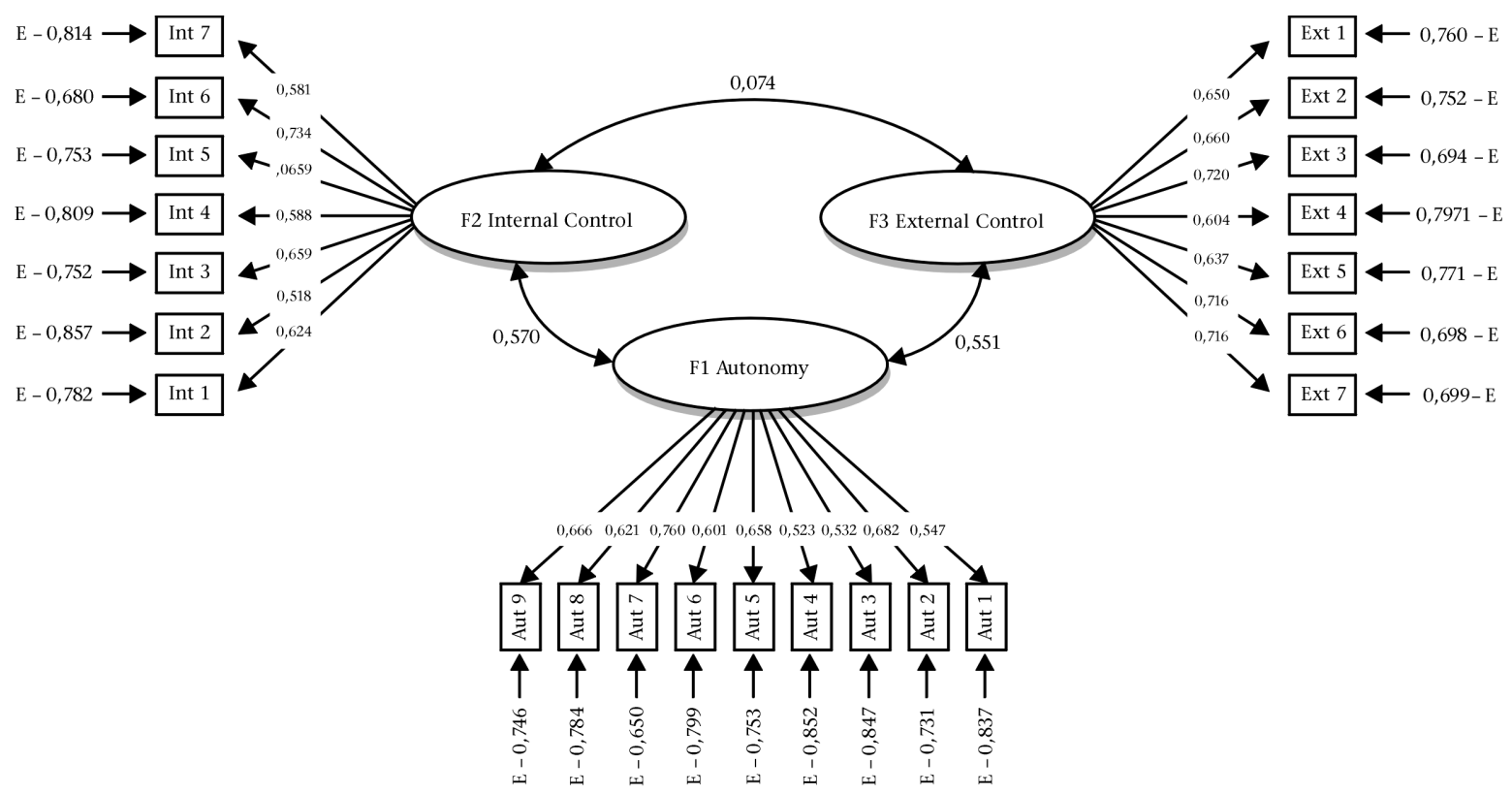

Figure 5: Standardised estimated parameters of the three-factor LCI model for first language respondents

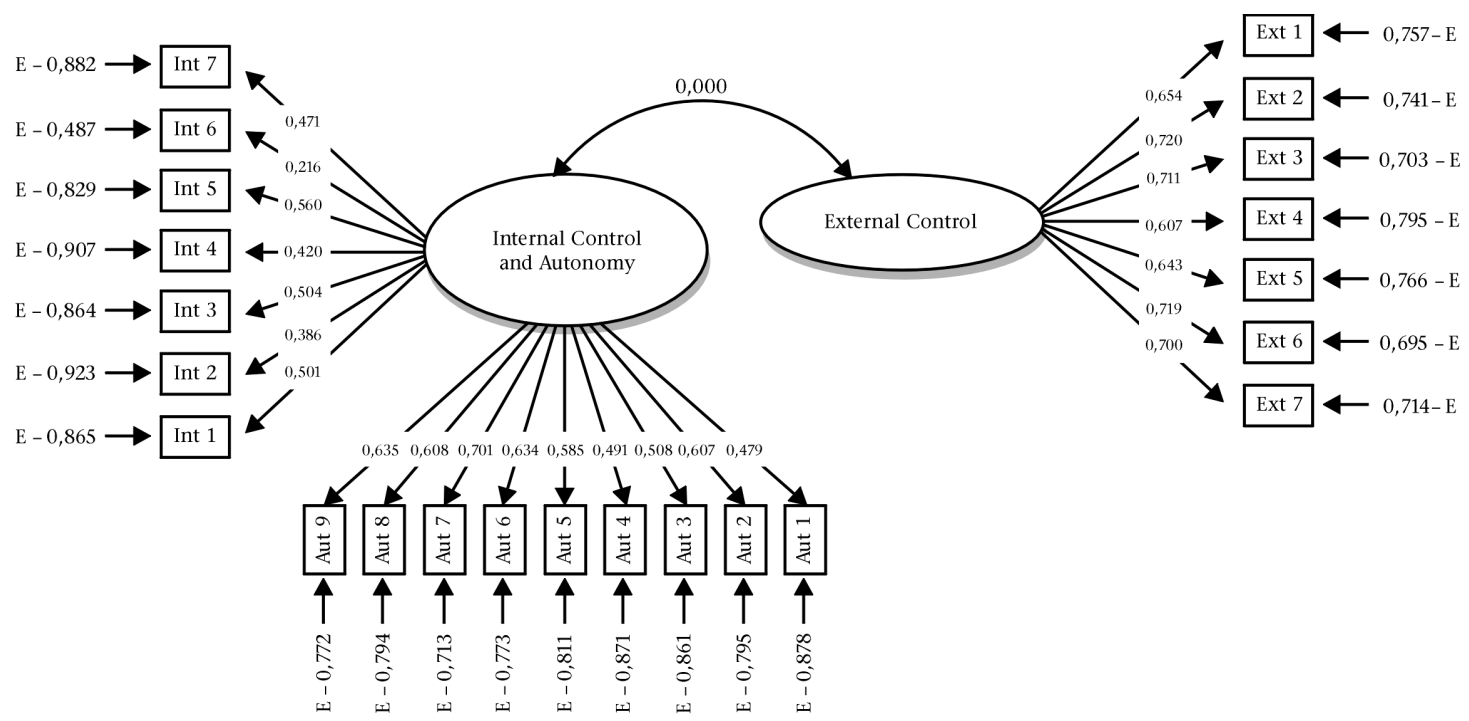

Figure 6: Standardised estimated parameters of the two-factor LCI model for the first language respondent 
TABLE 11

FIT INDICES FOR FIRST LANGUAGE RESPONDENTS

\begin{tabular}{lcc}
\hline $\begin{array}{c}\text { First language } \\
\text { respondents } \\
(\mathrm{N}=387)\end{array}$ & $\begin{array}{c}\text { Three factor } \\
\text { solution }\end{array}$ & $\begin{array}{c}\text { Two-factor } \\
\text { solution }\end{array}$ \\
\hline CHI Square & 569,724 & 969,247 \\
$(\mathrm{DF})$ & $(227)$ & $(228)$ \\
NFI & 0,819 & 0,692 \\
NNFI & 0,868 & 0,716 \\
CFI & 0,882 & 0,774 \\
IFI & 0,883 & 0,746 \\
RMSEA & 0,065 & 0,096 \\
\hline
\end{tabular}

\section{DISCUSSION}

Differences in the construct validity of the LCI for second and first language respondents included in this study are evident. The LCI, which was developed and standardized for respondents answering the questions in their first language (Afrikaans and English), appears to be less valid for second language respondents. The differences in mean values on the Autonomy and External Locus of Control scale scores are of little practical significance for the groups included in the study. The Internal Locus of Control scale could be of practical significance when comparisons between first and second language respondents are made and should be used with caution in such instances.

The reliability coefficients of the LCI for the second language and first language respondents both appear to be sufficient, but what can be questioned is the extent to which the scales can be equally interpreted for the groups in question. The Autonomy scale may be the greatest area of concern, because it is not equally valid for the second and first language respondents. The item analysis, reliability analysis and factor structures for the groups indicate clear differences in their response patterns for the scale. Interscale correlation analyses, factor loadings and confirmatory factor analyses indicate that second language respondents do not distinguised clearly between the Autonomy and Internal Locus of Control constructs. For first language respondents there is a clearer distinction between these constructs. The LCI appears to be factorially more pure for first language respondents than for second language respondents.

Although the External Locus of Control factor can be regarded as congruent for the groups included in the study, the reliability of the scale differs significantly for these groups. Comparisons between first and second language respondents regarding the External Locus of Control should thus be made with caution due to the differences in scale accuracy. The construct validity of the Internal Locus of Control scale appears not to differ substantially between second and first language respondents.

The study indicates that the LCI contains elements of bias in terms of construct validity for first and second language respondents. Various explanations can account for the differences between response patterns of the second and first language respondents, including linguistic proficiencies, attitudes, motivation, values and culture-specific differences (Owen and Taljaard, 1996). However, the low level of English language proficiency (Horne, 2001) is probably the best explanation for the differences in the construct validity of the
LCI for the first and second language groups in the study.

The extent to which other factors play a role in the differences shown here in the construct validity of the LCI for second and first language respondents is not known. Further studies need to be undertaken to explain the observed differences in construct validity.

\section{REFERENCES}

Anastasi, A. \& Urbina, D. (1997). Psychological Testing. New Jersey: Prentice-Hall.

Anastasi, A. (1990). Psychological Testing. New York: Macmillan.

Bentler, P.M. (1990) Comparitive fit indices in structural models. Psychological Bulletin, 107, 238-246.

Bentler, P.M. \& Bonnett, D.G. (1980). Significance tests and goodness of fit in the analysis of covariance structures. Psychological Bulletin, 88, 588-606.

Bogazzi, R.P. \& Heaterton, T.F. (1994). A general approach to presenting multifaceted personality constructs: Application to state self-esteem. Structural Equation Modelling, 1, 35-67.

Cattell, R.B. (1966). The scree test for the number of factors. Multivariate Behaviour Research, 1, 245-276.

Child, D. (1990). The essentials of factor analysis. London: Cassell Educational.

Cohen, J. (1988). Statistical power analysis for the behavioral sciences. Academic Press: Orlando.

Comrey, A.L. \& Lee, H.B. (1992). A first course in factor analysis. Hillsdale: Lawrence Erlbaum Associates.

Cronbach, L.J. \& Meehl, P.E. (1955). Construct validity in Psychological tests. Psychological Bulletin, 52, 281-302.

De Vellis, R.F. (1991). Scale development: theory and applications. Newbury Park: Sage.

Gorsuch, R.L. (1997). Exploratory factor analysis: Its role in item analysis. Journal of Personality Assessment, 68 (3), 532-560.

Hair, J.F., Anderson, R.E., Tatham, R.L. \& Black, W.C. (1995). Multivariate data analysis with readings. New Jersey: Prentice-Hall.

Hall, C.S. \& Lindzey, G. (1985). Introduction to Theories of Personality. New York: John Wiley.

Horn, J.L. (1965). A rationale and test for the number of factors in factor analysis. Psychometrika, 30 (2), 179-185.

Horne, T.J. (2001). Education and language transferees. Education Africa Forum, 5, 40-43.

Kaiser, H.F. (1961). A note on Guttman's lower bound for the number of common factors. British Journal of Statistical Psychology, 14 (1), 1.

Kanji, G.K. (1993). 100 statistical tests. London: Sage.

Kelloway, E.K. (1998). Using LISREL for structural equation modeling; a researcher's guide. Thousand Oaks: Sage.

Kim, J. \& Mueller, C.W. (1978). Factor analysis: Statistical methods and practical issues. Sage University Paper series on Quantitative Applications in the Social Sciences, series no 07014. Beverley Hills: Sage.

Medskar, G.J., Williams, L.J. \& Holahan, P.J. (1994). A review of current practices for evaluating causal models in organizational behavior and human resources management research. Journal of Management, 20, 439-464.

Owen, K. \& Taljaard, J.J. (1996). Handbook for the use of psychological and scholastic tests of the HSRC. Pretoria: Human Sciences Research Council.

Rigdon, E. (1996). What is Structural Equation Modeling? http://www.gsu.edu/ mkteer/sem.htm1.

Rotter, J.B. (1966). Generalized expectancies for internal versus external control of reinforcement. Psychological Monographs, 80 (1), no 609.

Rotter, J.B. (1975). Some problems and misconceptions related to the construct of internal versus external control of rein-forcement. Journal of Consulting and Clinical Psychology, 43, 56-67.

Schaap, P., Buys, M.A. \& Olckers, C. (2003). The construct validity of Schepers's Locus of Control Inventory for Black and White tertiary students. SA Journal of Industrial Psychology, 29 (1), 32-43. 
Schermerhorn, J.R., Hunt, J.G \& Osborn, R.N. (1997). Organizational Behavior. New York: John Wiley.

Schepers, J.M. (1995). Locus of control inventory. Unpublished Report, Johannesburg: Rand Afrikaans University.

Schepers, J.M. (1999). Die lokus van beheer-vraelys: Konstruksie en evaluering van 'n nuwe meetinstrument. Unpublished report, Johannesburg: Rand Afrikaans University.

Steiger, J.H. (1995). Manual to Statistica-SEPATH. Tulsa: Statsoft.

Tabachnick, B.G. \& Fidell, L.S. (1989). Using multivariate statistics. New York: Harper Collins.

Tinsley, H.E.A. \& Tinsley, D.J. (1987). Uses of factor analysis in counselling psychology research. Journal of Counselling Psychology, 34, 414-424.

Tucker, L.R. (1951). A method for synthesis of factor analysis studies. Personnel Research Section Report, No 984. Washington: Department of the Army.

Wise, M. (1999). Taking control of our lives: The far-reaching effects of locus of control. http://miavx1.muohio.edu/ psybersite/ control/overview.htx.

Zwick, W.R. \& Velicer, W.F. (1986). A comparison of five rules for determining the number of components in complex data sets. Psychological Bulletin, 99, 432-442. 